CASE NOTE

\title{
MULOWAYI v MINISTER OF HOME AFFAIRS [2019] ZACC 1 (29 JANUARY 2019)
}

\author{
JO VENKOV*
}

TABLE OF CONTENTS

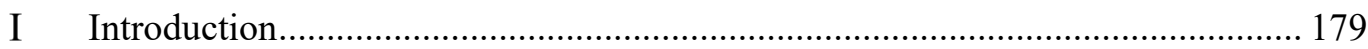

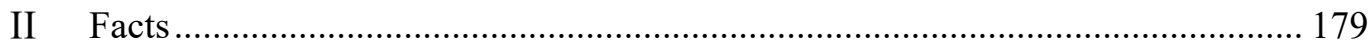

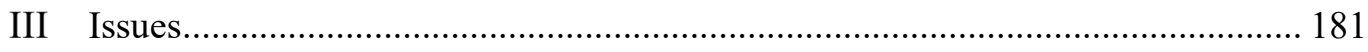

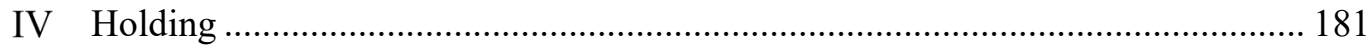

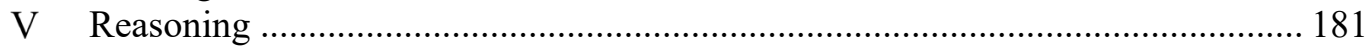

A The Law on Acquisition of South African Citizenship by Birth .............. 181

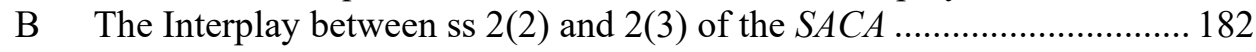

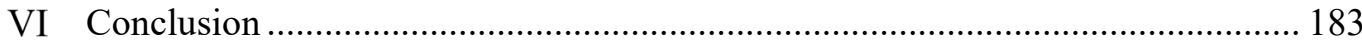

\section{INTRODUCTION}

Mulowayi v Minister of Home Affairs ('Mulowayi') is an appeal to the South African Constitutional Court ('Constitutional Court') from a decision of the High Court of South Africa ('High Court') dealing with the validity of a regulation amending the South African Citizenship Act ('SACA'). ${ }^{1}$

Although the Constitutional Court's decision deals with the error of the High Court, some of the judgment is devoted to a discussion on the status of the third applicant, Mr and Mrs Mulowayi's son Gaddiel. Gaddiel is stateless and faces legal and practical obstacles to obtaining South African citizenship. ${ }^{2}$ It is the Constitutional Court's obiter comments on the wider issues arising from South Africa's citizenship regime - especially as they affect stateless people — that are of most interest. Navigating complex administrative processes to give effect to rights available under citizenship laws is one of the hurdles that many stateless people face. Mulowayi shows that such hurdles impact stateless people living in South Africa today.

\section{FACTS}

$\mathrm{Mr}$ and Mrs Mulowayi are refugees from the Democratic Republic of Congo ('DRC'), who arrived in South Africa around 2002. ${ }^{3}$ On 1 February 2011 and 5

* Jo Venkov is a lawyer and the author of The Torn Identity $(\mathrm{Blog})<$ www.thetornidentity.org $>$, which analyses and discusses the legal aspects of identity such as statelessness, citizenship, documentation, belonging and being disenfranchised through a lack of identity. She can be contacted atinfo@thetornidentity.org.

1 Mulowayi v Minister of Home Affairs [2019] ZACC 1 ('Mulowayi'); High Court of South Africa, Western Cape Division; South African Citizenship Act 1995 (South Africa) ('SACA').

2 Mulowayi (n 1) 3 [5], [12].

3 Mulowayi v Minister of Home Affairs; Eisenberg Attorneys v Minister of Home Affairs [2018] Case Nos 13550/2017 and 8542/2017 (unreported) (High Court of South Africa, Western Cape Division). 
May 2011, respectively, the couple were granted permanent residency. ${ }^{4}$ The couple has three children, all born in South Africa after their parents were granted permanent residency. ${ }^{5}$ The two older children are recognised as South African citizens by birth. ${ }^{6}$ The youngest, Gaddiel, who is the third applicant, is not, although his birth in 2017 was registered in compliance with the Births and Deaths Registration Act. ${ }^{7}$ Gaddiel was born after the amendments to the SACA came into force. ${ }^{8}$ Those amendments remove the right of children of South African permanent residents to qualify for citizenship at birth. ${ }^{9}$

$\mathrm{Mr}$ and Mrs Mulowayi sought to naturalise in South Africa. ${ }^{10}$ Upon making inquiries, officials at the Home Affairs Department informed the couple that they must wait at least five years before making their application and also that they must renounce their Congolese citizenship, in compliance with $S A C A .^{11}$ In December 2015, the applicants renounced their Congolese citizenship and in 2016, they applied for naturalisation. ${ }^{12}$ In October 2016, the Director-General of the Home Affairs Department ('Director-General') refused their application on the basis that reg 3(2)(a) creates a minimum period of 10 years permanent residency as qualification for citizenship. ${ }^{13}$ As a result of this decision, and since the first and second applicant had renounced their Congolese citizenship, all three applicants are stateless. ${ }^{14}$

The High Court ruled reg 3(2)(a) to be ultra vires, irrational and inconsistent with s 238 of the Constitution of the Republic of South Africa ('Constitution') and therefore invalid. ${ }^{15}$ However, it suspended the declaration of invalidity pending a confirmation of its order by the Constitutional Court. ${ }^{16}$ The High Court set aside the decision of the Director-General and directed that the application be reconsidered within two months. ${ }^{17}$ The High Court was silent with respect to Gaddiel, other than that he ought to be placed in a position where he too can qualify for South African citizenship. ${ }^{18}$

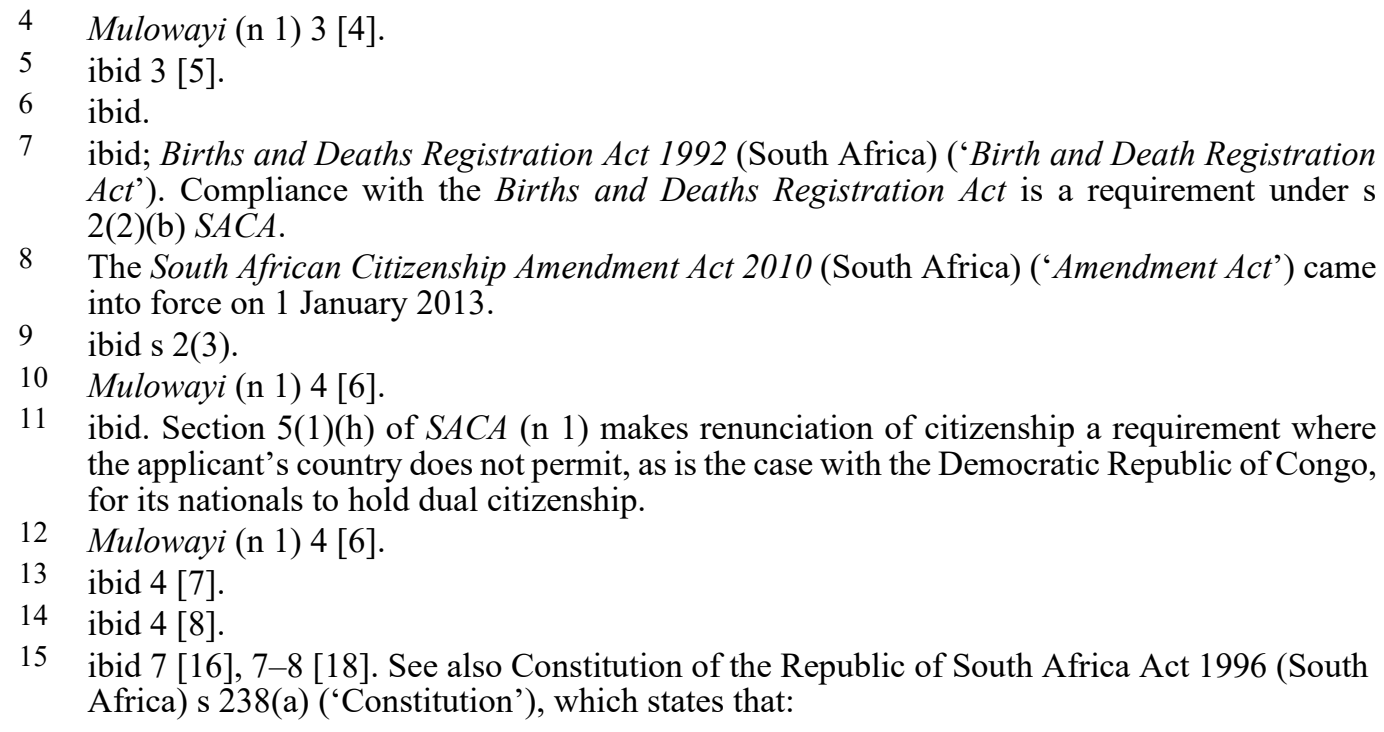

8 The South African Citizenship Amendment Act 2010 (South Africa) ('Amendment Act') came into force on 1 January 2013.

9 ibid s 2(3).

10 Mulowayi (n 1) 4 [6].

11 ibid. Section 5(1)(h) of SACA (n 1) makes renunciation of citizenship a requirement where the applicant's country does not permit, as is the case with the Democratic Republic of Congo, for its nationals to hold dual citizenship.

12 Mulowayi (n 1) 4 [6].

13 ibid 4 [7].

14 ibid $4[8]$.

15 ibid 7 [16], 7-8 [18]. See also Constitution of the Republic of South Africa Act 1996 (South Africa) s 238(a) ('Constitution'), which states that:

An executive organ of state in any sphere of government may-

delegate any power or function that is to be exercised or performed in terms of legislation to any other executive organ of state, provided the delegation is consistent with the legislation in terms of which the power is exercised or the function is performed.

16 Mulowayi (n 1) 8 [19].

17 ibid 8 [19].

18 ibid 7 [17]. 


\section{ISSUES}

Mr and Mrs Mulowayi, appealing the decision of the High Court, sought the following remedies: that the declaration of the High Court be confirmed or, in the alternative, for the suspension of the order to be lifted. ${ }^{19}$

The legal issues for the Constitutional Court are two-fold. First, whether the High Court was correct to make an order that reg 3(2)(a) is invalid. ${ }^{20}$ Reg 3(2)(a) of the Regulations on the South African Citizenship Act ('Regulations') sets the required period of permanent residency prior to eligibility for naturalisation to 10 years. ${ }^{21}$ This period contradicts s 5(1) of the $S A C A$, the primary legislation, where the minimum period is five years. ${ }^{22}$ The Constitutional Court then considered whether the High Court was right to suspend the operation of its own order pending confirmation of that order by the Constitutional Court. ${ }^{23}$ The suspension of the order left the applicants without effective relief as reg 3(2)(a), and the 10 year period, remain in force.

The second issue, which is the focus of this case note, is as to the effective relief available to Gaddiel in light of the Home Affairs Department's refusal to consider his application for citizenship. ${ }^{24}$

\section{HOLDING}

The Constitutional Court followed its own precedent, Minister of Home Affairs $v$ Liebenberg, and found that a declaration of invalidity of a regulation does not fall within s 172 of the Constitution and does not require confirmation by the Constitutional Court. ${ }^{25}$

On the alternative ground of appeal, the Constitutional Court gave leave to appeal and held that the High Court erred in its decision to suspend its own order. ${ }^{26}$ The decision of the High Court suspending its own order was set aside. ${ }^{27}$ The original order of the High Court was restored. The only relevant period to take into account when applying for naturalisation was the five-year period set out in $\mathrm{s}$ $5(1)(c)$ of the $S A C A$.

\section{REASONING}

\section{A The Law on Acquisition of South African Citizenship by Birth}

Prior to the 2010 amendment to the $S A C A$, any child born to a permanent resident would be immediately considered a citizen of South Africa by birth. ${ }^{28}$ As the 2010

19 ibid 8 [20].

20 Mulowayi (n 1) 2 [3].

21 Regulations on the South African Citizenship Act 1995 (South Africa).

22 SACA (n 1).

23 Mulowayi (n 1) 3 [1].

24 ibid 11 [32].

25 Minister of Home Affairs v Liebenberg [2001] ZACC 3, 7-9 [13] (South African Constitutional Court); Mulowayi (n 1) 10-11 [28]. Section 172(2)(a) of the Constitution requires that an order of the Hight Court invalidating primary legislation, a provincial Act, or any act of the President is without force unless confirmed by the Constitutional Court. Mulowayi (n 1) 11-12 [33].

27 ibid 12 [34].

28 The Amendment Act (n 8) came into force on 1 January 2013; SACA (n 1) s 2(2). 
amendments did not come into force until January 2013, Gaddiel's siblings both benefited from an application of the unamended provisions of the $S A C A$ and were registered as South African citizens by birth. ${ }^{29}$ Gaddiel was born in 2017 and, as such, his status is governed by the amended s 2 of the $S A C A .{ }^{30}$

The amended s 2 of the $S A C A$ sets out three routes to citizenship. The first is to be born either within or outside South Africa to a parent who is a South African citizen. ${ }^{31}$ This route is not open to Gaddiel since neither of his parents were South African citizens at the time of his birth. ${ }^{32}$ The second route applies to a person who is not a citizen or national of any other country or has no right to such citizenship or nationality and who is registered in accordance with the Births and Deaths Registration Act. ${ }^{33}$ Currently Gaddiel is stateless as he does not have South African nationality and was born after his parents had renounced their Congolese nationality. Having never lived in the DRC and without his parents being Congolese citizens, Gaddiel is not eligible for Congolese citizenship. The third route is open to a person who was born in South Africa to parents with permanent residency in South Africa, and who has lived his or her whole life in South Africa. ${ }^{34}$ As per the 2010 amendments to the $S A C A$, applications can only be made by those who have attained the age of majority. ${ }^{35}$ Under this route, Gaddiel would have to wait until March 2035 before he could apply for citizenship.

\section{$B \quad$ The Interplay between ss 2(2) and 2(3) of the SACA}

The 2010 amendment to the $S A C A$ restricts the right to citizenship under s 2(3) to those who have reached the age of majority. ${ }^{36}$ The judge's obiter comments highlight that the route to citizenship available to Gaddiel under s 2(3) of the $S A C A$ is a breach of his constitutional right to nationality because it 'was not in accordance with the right of the child to a nationality as set out in s 28(1)(a) of the Constitution'. 37

South Africa is a signatory to the Convention on the Rights of the Child (' $C R C$ '). ${ }^{38}$ The $C R C$ was, in fact, the first treaty the new democratic government ratified. It is not surprising that the language of the Constitution, in force the following year, reflects the wording of art 7 of the $C R C$, which recognises that children have a right from birth to a name and to acquire a nationality. ${ }^{39}$ Regional treaties such as the 1990 African Charter on the Rights and Welfare of the Child ('African Charter'), to which South Africa is also a party, confirm the rights enshrined in art 7 of the $C R C .40$ The African Committee of Experts on the Rights

29 Amendment Act (n 8). It appears that the sibling born in February 2013, after the 2010 amendment came into force, was treated as a citizen by birth in error.

30 ibid.

31 SACA (n 1) s 2(1)(b).

32 Mulowayi (n 1) 3 [4]-[5].

33 SACA (n 1) s 2(2); Births and Deaths Registration Act (n 7).

34 SACA (n 1) s 2(3).

35 Amendment Act (n 8) s 2(3).

36 ibid.

37 Mulowayi (n 1) 7 [17].

38 Convention on the Rights of the Child, opened for signature 20 November 1989, 1577 UNTS 3 (entered into force 2 September 1990) ('CRC').

39 ibid art 7; Constitution (n 15) s 28(1)(a).

40 Organization of African Unity, African Charter on the Rights and Welfare of the Child, Doc No CAB/LEG/24.9/49(1990), 11 July 1990, art 6 ('African Charter'); CRC (n 38) art 7. 
and Welfare of the Child ('ACERWC') has made it clear that state parties should not make children wait until the age of majority to obtain citizenship. ${ }^{41}$

The restrictions in s 2(3) of the $S A C A$, as amended, are - in theory - cured by the provisions in s 2(2). ${ }^{42}$ Section 2(3) allows minors who are citizens of another country to apply for South African citizenship at the age of majority. ${ }^{43}$ For those who have no nationality at all, s 2(2) grants them South African citizenship from birth so that they are not left stateless. ${ }^{44}$ Sections $2(3)$ and (2) complement each other and ensure compliance both with the Constitution and with its international legal obligations. ${ }^{45}$

The Constitutional Court's decision touches on the issue of the third applicant's statelessness and the impact it will have on his life, including the difficulty he would face in obtaining medical care and access to education. ${ }^{46}$ It is strange, however, that the Court does not comment on Gaddiel's eligibility to citizenship by birth under s 2(2) of the $S A C A .{ }^{47}$ Perhaps one reason for this is that there are no regulations setting out how a stateless person might make an application under s 2(2). Usually, the routes to citizenship available under the $S A C A$ are made accessible by the provision of an application form set out in regulations. In Minister of Home Affairs $v$ DGLR, the need for such regulations was spelled out and the Supreme Court of Appeal ordered the Home Affairs Department to make such regulations. ${ }^{48}$ Although four years have passed since the judgment in DGLR, to date the Home Affairs Department has not complied with the Court order.

\section{CONCLUSION}

The Court does not go into detail on the lawfulness of s 2(3) of the $S A C A$, but clearly the section's validity is on its radar, especially in light of s 28(1) of the Constitution, the provisions of the CRC, the African Charter and ACERWC's

41 The African Committee of Experts on the Rights and Welfare of the Child ('ACERWC') is the body empowered to receive and examine reports by parties to the African Charter on the measures they have adopted to implement provisions of the African Charter and the progress achieved protecting rights under the African Charter. See African Committee of Experts on the Rights and Welfare of the Child, General Comment No 2 on Article 6 of the African Charter on the Rights and Welfare of the Child: 'The Right to a Name, Registration at Birth, and to Acquire a Nationality', Doc No ACERWC/GC/02 (2014), 16 April 2014 [92] ('General Comment'). See also African Committee of Experts on the Rights and Welfare of the Child, Institute for Human Rights and Development in Africa (IHRDA) and Open Society Justice Initiative on Behalf of Children of Nubian Descent Kenya v The Government of Kenya, Decision No. 002/Com/002/2009, 22 March 2011 [42] ('ACERWC's Decision'). The $A C E R W C$ 's Decision states that 'the practice of making children wait until they turn 18 years of age to apply to acquire a nationality cannot be seen as an effort on the part of the State Party to comply with its children's rights obligations'. This practice is 'neither in line with the spirit and purpose of Article 6, nor promotes children's best interests, and therefore constitutes a violation of the [African Charter]'. The Committee does not limit itself to making this comment specifically about stateless children (who may have another remedy under national laws) but makes the wider point that such provisions create a risk of statelessness.

42 SACA (n 1).

43 ibid.

44 ibid.

45 ibid; Constitution (n 15).

46 Mulowayi (n 1) 6 [12].

47 ibid 11 [32]; SACA (n 1).

48 Minister of Home Affairs v DGLR [2016] 1051/2015 (Supreme Court of Appeal of South Africa) (Registrar Myburgh) ('DGLR'). 
view that every child is entitled to a nationality. ${ }^{49}$ If a child has to wait until the age of majority to have a nationality, he or she is by definition, no longer a child. A helpful step forward would have been for the Court to refer to the order of the Supreme Court of Appeal in Minister of Home Affairs $v$ DGLR and to press for regulations to allow stateless individuals to apply for citizenship under s 2(2) of the $S A C A .50$

A future case on the lawfulness of s 2(3) of the $S A C A$ will hopefully cause the Court to consider the interplay between ss 2(2) and 2(3) and whether the Home Affairs Department can continue to ignore the need for regulations giving full effect to s 2(2) of the $S A C A .{ }^{51}$ Without such regulations, Gaddiel is left without an effective remedy until the year 2035, unless he engages in further litigation.

49 SACA (n 1); Constitution (n 15); CRC (n 38); African Charter (n 40); General Comment (n 41); ACERWC's Decision (n 41).

$50 \quad D L G R(\mathrm{n} 48)$

$51 S A C A$ (n 1). 